International Journal of Business Management and Economic Review

Vol. 4, No. 06; 2021

ISSN: 2581-4664

\title{
THE EFFECT OF PARTICIPATION IN BUDGETING, UTILIZATION OF \\ INFORMATION TECHNOLOGY, ROLE OF INTERNAL CONTROL AND \\ APPARATUS COMPETENCY ON MANAGERIAL PERFORMANCE \\ (Study on the Aceh Singkil District's Government Work Unit, Aceh Province, Indonesia)
}

\author{
Ermida, Muslim A. Djalil* and Mulia Saputra \\ Magister of Accountancy, Faculty of Economics and Business, Universitas Syiah Kuala, Banda Aceh, Indonesia
}

http://doi.org/10.35409/IJBMER.2021.3327

\begin{abstract}
This study aims at examining the effect of participation in budgeting, use of information technology, the role of internal control and the competence of the apparatus, both simultenouesly and partially on the managerial performance of District's government Work Unit (SKPK) Aceh Singkil. The population in this research is SKPK which includes offices, and agencies in Aceh Singkil. Meanwhile, the respondents are Head of SKPK, Financial Administration Officers, and Technical Operators of the agency with a total of 138 respondents. The data source in this study uses primary data that taken through distribution of questionnaires to respondents. While the research data collection technique is done by using documentation technique. The analytical method used is Multiple Linear Regression Analysis. The results showed that the participation in budgeting, the use of information technology, the role of internal control and the competence of the apparatus simultenouesly and partially influenced the managerial performance of SKPK in Aceh Singkil District.
\end{abstract}

Keyword: Participation in Budgeting, Utilization of Information Technology, Role of Internal Control, Apparatus Competence, Managerial Performance.

\section{INTRODUCTION}

Local government performance is a description of the level of achievement of the results of the implementation of an activity/program/regional government policy in realizing the goals, objectives, mission and vision of the region as stated in regional planning documents. The performance of local government can be informed to the public and stakeholders regarding the level of achievement of results, related to the mission and vision of the organization, as well as the positive and negative impacts of operational policies that have been taken (Chabib, 2011).

Measuring the performance of the public sector is not like the business/private sector where the measurement of its performance is clear and definite, namely mainly profit, the public sector is much more complex, especially on managerial performance. Managerial performance shows the ability and achievements of a manager in running the organization to achieve goals that lead to the achievement of public services. The interest of managerial performance is needed to assess how far an institution/organization can implement its vision and mission so that public services can be realized. One form of consistency is the need to carry out a form of activity, namely to collect people's aspirations and the existence 


\section{International Journal of Business Management and Economic Review}

Vol. 4, No. 06; 2021

ISSN: 2581-4664

of clarity in integrated budgeting participation so that a system can be achieved that can prevent or minimize errors in realizing good governance.

Not only in the central government, managerial performance problems are also experienced by local governments such as in Aceh Singkil District. The current phenomenon is the low managerial performance in the Aceh Singkil District Work Unit (SKPK). According to the Deputy Regent of Aceh Singkil, currently the problems that occur are related to the performance of the State Civil Apparatus (ASN) in the implementation of E-performance, namely that not all work is completed by the ASN itself, but is delegated to honorary staff to input ASN activities. This can result in a decrease in the performance of the ASN. These ASN performance problems also have an impact on the managerial performance assessment of SKPK, namely structural officials, to provide an objective assessment of their subordinate apparatus (Barus, 2019).

In addition to these problems, the weak managerial performance of the Aceh Singkil SKPK can also be seen in the Aceh Singkil Regional Government Financial Audit Report (LHP LKPD) for the 2018 Fiscal Year. There are several findings such as: Changes in the Aceh Singkil Regency Government Budget are inadequate; The budgeting error for goods and services expenditures at the Agriculture Service was Rp. 1,197,030,000.00; The realization of operational support spending for regional heads and deputy regional heads exceeds the stipulated amount of Rp. 37,809,679.24; The excess of payment for the three packages of activities at the Department of Industry, Trade, Cooperatives and Small and Medium Enterprises is Rp. 41,843,743.15. and a lack of revenue of Rp. 55,171,000.00 (LHP LKPD, 2019).

Based on these findings, it can be assessed that the managerial performance of SKPK Aceh Singkil is not yet fully good, such as the application of E-performance and findings in LKPK that have an impact on the assessment of its managerial performance. To improve managerial performance in an organization cannot be separated from the various factors that influence it. Many factors determine a successful organization in improving performance, both those that have been proven empirically by previous researchers, as well as factors that have not been included in the research.

Firstly, budgetary participation has an effect on managerial performance. The manager's performance will be said to be effective if the organizational goals that have been recorded in the budget can be achieved. Participation can improve performance because participation allows subordinates to communicate what they need to their superiors and participation can allow subordinates to choose actions that can build commitment and are considered responsibility for what has been chosen. Therefore, participation in this case is expected to improve overall managerial performance. This is in accordance with the results of research by Puspita (2018), Sukandani and Istikhoroh (2016), Friyanty (2016), Sari (2015), Hidayat (2014), Rasuli and Lukum (2012). Their research results prove that budgetary participation has an effect on managerial performance.

Secondly, the use of information technology has an effect on managerial performance. The application of technology in a company / organization's information system should consider system users so that the technology applied can be useful in accordance with the duties and capabilities of the user. It is not uncommon to find that the 
technology applied in information systems is often inappropriate or not fully utilized by system users so that the application of information systems does not provide any benefits or even no benefit at all in increasing individual performance (Jumaili, 2005). This is in accordance with the research results of Sari, Basri and Indriani (2017), Wasito (2012) which prove that the use of information technology has an influence on individual/managerial performance.

Thirdly, the role of internal control has an effect on managerial performance. According to Mardiasmo (2001), one of the factors that can improve managerial performance is internal control. With this supervision at every stage of financial management, it is hoped that the financial management process, especially in the budget formulation process, will increase its influence on the work unit's managerial performance. This is in accordance with the results of research by Puspita (2018) and Sari (2015) which prove that the role of internal control affects managerial performance.

Fourthly, the competence of the apparatus has an effect on managerial performance. To produce good performance, it must be supported by adequate human resources. If the available human resources are competent in their fields, the performance created will be as needed and according to what they should be (Revika, 2015). This shows that Managerial must have good abilities in carrying out their duties so that the results of Managerial performance are relevant and reliable. This is in accordance with the research results of Sari, Basri and Indriani (2017), Wasana and Wirajaya (2015) which prove that apparatus competence affects managerial performance.

Research in the budget sector in the government sector has been carried out with mixed results. This occurs considering that the preparation of the budget involves many dimensions, including the human being as the compiler of the budget, the characteristics of the budget itself and the characteristics of the organization. Based on these conditions, the phenomenon of the budget is still an interesting topic to research. This study is different from previous research when viewed from the use of variables, the selection of research objects and the method of analysis used.

\section{LITERATURE REVIEW \\ Managerial Performance}

Apparatus performance is seen based on the apparatus' ability to carry out managerial tasks which include planning, investigation, coordination, supervision, staff management, negotiation and representation (Mahoney in Leach-Lopez et al. 2007). According to Santoso in Wulandari (2011), there are several factors that are suspected of causing low regional government performance, including due to the weak regional financial management system, starting in the APBD planning and budgeting process, District's Revenue and Expenditure Budget (APBD) implementation/administration, accountability in the form of reporting the results of APBD implementation and supervision. Furthermore, what is meant by managerial performance is the performance of individuals in managerial activities, such as: planning, investigation, coordination, evaluation, supervision, staffing, negotiation and representation (Mah Oney, 1963). According to Supomo and Indriantoro (1998) managerial performance is the performance of individual members of the organization in managerial activities, including: planning, coordination, 


\section{International Journal of Business Management and Economic Review}

Vol. 4, No. 06; 2021

ISSN: 2581-4664

supervision, staffing, negotiation, and representation. For the organization itself, managerial performance can be a measure of the extent to which managers carry out management functions .

\section{Participation in Budgeting}

According to Brownell in Coryanata (2004:619) participation is a behavior, work, and activity carried out by government officials during budget preparation activities. Participation in budgeting is needed because the budget is made in accordance with the existing reality. Participation in budgeting is a feature of budget preparation that emphasizes the participation of local government officials to be accountable for the budget preparation process. Meanwhile, according to Munandar (2000) budget is a plan that is systematically compiled which includes all government activities stated in monetary units (unity) and is valid for a certain future period. Brownell and Innes (1986) stated that participation in budgeting is a process of individual participation that will be evaluated and possibly rewarded based on their achievement on goals. Based on the previous explanation, what is meant by participation in budgeting is SKPK's managerial participation in the regional budgeting process, such as programs and activities to be implemented, participation in determining targets and budgets and so on (Bangun, 2009) .

\section{Utilization of Information Technology}

According to O'Brien (2006:28) technology is a computer network consisting of various information processing components that use various types of hardware, software, data management and information network technology. Information according to Supriono (2005:6) is data that is processed and its nature becomes other useful data and is commonly called information. Information Technology Association of American (ITAA) in Sutarman (2009,3) defines information technology as a study, design, development, implementation, support or management of computer-based information systems, especially software applications and computer hardware. Information technology makes use of electronic computers and software to change, store, protect, process, transmit and obtain information safely. Furthermore, what is meant by the use of information technology is an activity that includes data processing, information processing, management systems and work processes electronically. and the use of advances in information technology so that public services can be accessed easily and cheaply by people throughout the country (Celviana and Rahmawati, 2010). The use of information technology according to Jurnali and Supomo (2002) is the level of integration of information technology in the implementation of tasks.

\section{Role of Internal Control}

Sabeni and Gozali (2001:67) define internal control as a supervisory tool from the leadership of the organization concerned to oversee whether the activities of their subordinates are in accordance with predetermined plans and policies. P engawasan an integral stage by stage in the overall preparation and reporting of the state budget. Supervision is needed at every stage not only at the evaluation stage (Mardiasmo, 2001) Supervision is carried out by the implementation of the APBN and APBN Accountability. With the supervision in each taha pan financial management center, then the process of financial management, especially in the budgeting process will enlarge its influence on managerial performance Unit. Internal supervision aims to assess the management control system, efficiency and 


\section{International Journal of Business Management and Economic Review}

Vol. 4, No. 06; 2021

ISSN: 2581-4664

effectiveness of the implementation of main tasks and functions as well as compliance with laws and regulations in order to improve and/or enhance agency performance. All internal control activities must be a comprehensive effort in building a government internal control system through the development of a good management culture and ethics, analysis and risk management (Mifti, Lestariyo and Kowanda, 2009).

\section{Apparatus Competence}

Competence is a basic characteristic that a person has that has a direct effect on one's success in the workplace, or can predict very good work (McClelland, 1973 in Dermawan, 2016). Competence is defined as a basic characteristic of a person that enables him to provide superior work in a particular job, role, or situation (Sutrisno, 2009). Thus, competence is a person's ability to carry out a job according to his abilities and expertise. So someone who does not have competence in their field of work will experience problems in carrying out their work.

\section{RESEARCH METHOD}

This research is a census research because all members of the population are made respondents. The population of this research is institutions/institutions, namely SKPK which includes offices, services and agencies in Aceh Singkil. Each SKPK will be assigned 3 (three) people as respondents, namely; Head of SKPK, PPK (Financial Administration Officer), and PPTK (Technical Implementation Officer), so that the total number of respondents was 138 people (46 SKPK x 3 respondents). Sources of data in this study using primary data, namely the acquisition of questionnaires from respondents. While the research data collection technique was carried out by using documentation techniques. The analytical method used is Multiple Linear Regression Analysis.

Operationalization of variables in this study can be described as follows;

a. Managerial Performance (Y), namely the performance of individuals as managerial parties in carrying out their duties / managerial activities (Mahoney 1963). Indicators or measuring tools used based on Mahoney in Leach-Lopez et al. (2007) namely; effectiveness of planning results, effectiveness of budgeting results, effectiveness of administration results, effectiveness of reporting results, effectiveness of monitoring results, effectiveness of staffing results. The measurement scale used is an interval scale in the form of a 5-point Likert scale.

b. Participation in budgeting $\left(\mathrm{X}_{1}\right)$, namely SKPA managerial participation in the regional budgeting process, such as programs and activities to be implemented, participation in determining targets and budgets and so on (Bangun, 2009). Indicators or measuring instruments used based on Milani (1975), namely; participation, contribution, involvement, request for opinion, giving opinion, influence of participation. The measurement scale used is an interval scale in the form of a 5-point Likert scale.

c. Utilization of Information Technology $\left(\mathrm{X}_{2}\right)$, namely the use of a technology used to obtain, transmit, process, interpret, store, organize, and use data meaningfully to obtain quality information. Indicators or measuring instruments used based on Celviana and Rahmawati (2010) include; devices, financial data management, and maintenance. The measurement scale used is an interval scale in the form of a 5-point Likert scale. 
d. The role of Internal Control $\left(\mathrm{X}_{3}\right)$, Sabeni and Gozali (1997:67) defines internal control as a supervisory tool from the leadership of the organization concerned to oversee whether the activities of their subordinates are in accordance with predetermined plans and policies. The indicators used are based on Permendagri Number 23 of 2007, namely; inspection, monitoring and evaluation. The measurement scale used is an interval scale in the form of a 5-point Likert scale.

e. Apparatus Competence $\left(\mathrm{X}_{4}\right)$, namely the basic characteristics of a person that directly affects one's success in the workplace, or can predict a very good job. Indicators used by Benefactor (2016), namely, skills (skills), knowledge (knowledge), abilities (ability). The measurement scale used is an interval scale in the form of a 5-point Likert scale.

\section{RESULTS AND DISCUSSIONS \\ Results \\ Descriptive Analysis}

Descriptive analysis for each variable in this study was obtained by questionnaires filled out by respondents to the variable; managerial performance $(\mathrm{Y})$, budgetary participation $\left(\mathrm{X}_{1}\right)$, utilization of information technology $\left(\mathrm{X}_{2}\right)$, the role of internal control $\left(\mathrm{X}_{3}\right)$, and apparatus competence $\left(\mathrm{X}_{4}\right)$. The following are descriptive statistical values for each of the research variables on the Table 1 below.

\section{Tabel 1 Descriptive statistics}

\begin{tabular}{|l|l|l|l|l|}
\hline & Average & $\begin{array}{l}\text { Standard } \\
\text { Deviation }\end{array}$ & Minimum & Maximum \\
\hline $\begin{array}{l}\text { Managerial } \\
\text { Performance }\end{array}$ & 4,12 & 0,30 & 3,33 & 4,58 \\
\hline $\begin{array}{l}\text { Participation in } \\
\text { Budgeting }\end{array} \quad 4,04$ & 0,34 & 3,33 & 4,72 \\
\hline $\begin{array}{l}\text { Utilization } \\
\text { Information } \\
\text { Technology }\end{array}$ & 4,00 & 0,38 & 3,00 & 4,83 \\
\hline Role of internal control & 4,03 & 0,31 & 3,33 & 5,00 \\
\hline Apparatus Competence & 3,86 & 0,32 & 3,00 & 4,50 \\
\hline
\end{tabular}

Based on the results of descriptive statistics, it can be seen that the four research variables, managerial performance $(\mathrm{Y})$, participation in budgeting $\left(\mathrm{X}_{1}\right)$, utilization of information technology $\left(X_{2}\right)$, the role of internal control $\left(X_{3}\right)$, and apparatus competence $\left(X_{4}\right)$ show an average value greater than the standard deviation value. This indicates that the four research variables have a more stable rate of data distribution. It can also be seen from the difference in the minimum and maximum values of the four variables which have a range that is not too far.

\section{Research Instrument Testing Results}

a. Based on the results of testing the validity shows that the correlation coefficient obtained from each variable item managerial performance $(\mathrm{Y})$, participation in budgeting $\left(\mathrm{X}_{1}\right)$, utilization of 


\section{International Journal of Business Management and Economic Review}

Vol. 4, No. 06; 2021

ISSN: 2581-4664

information technology $\left(\mathrm{X}_{2}\right)$, the role of internal control $\left(\mathrm{X}_{3}\right)$, and apparatus competence $\left(\mathrm{X}_{4}\right)$ are all above critical value of product moment correlation (correlation coefficient $>0,291$ ) so that the questionnaire used can be declared valid.

b. Based on the $p$ engujian reliability in mind that each instrument in this study reliable (reliably) because the value Cronb ach's Alpha greater than 0,6. So it can be concluded that the questionnaire used as a measurement tool in this study is feasible to use (reliable).

\section{Classical Assumption Testing Results}

Based on the histogram graph, it is known that the observation data is normally distributed where the curve is normal. While the P-Plot graph is known that the points move in the direction of the linear line, so it can be concluded that the research regression model is linear.

Based on the figure tolerance of variable participation in budgeting $\left(\mathrm{X}_{1}\right)$, utilization of information technology $\left(\mathrm{X}_{2}\right)$, the role of internal control $\left(\mathrm{X}_{3}\right)$, and apparatus competence $\left(\mathrm{X}_{4}\right)>0,10$, which means that no multikoline a rity between the independent variables. Meanwhile, the VIF value calculation results also showed that none of the independent variables that have a VIF value of more than 10. Thus, it can be concluded that in this study the regression model did not happen multikoline a rity between the independent variables.

From the graph scatterplot is known that there is no particular pattern in the chart, therefore it can be concluded that the regression model in this study is homoskedastisitas or not happen heteroskedastisitas.

\section{Regression Testing Results}

The results of testing the research regression can be seen in Table 2 .

Table 2 Research Regression Testing Results

\begin{tabular}{|l|l|l|l|l|}
\hline No. & Variable Name & $\begin{array}{l}\text { Regression } \\
\text { Coefficient } \\
(\beta)\end{array}$ & Resolutions & Conclusion \\
\hline 1 & Participation in Budgeting $\left(\mathrm{X}_{1}\right)$ & 0,592 & $\beta \neq 0$ & Take effect \\
\hline 2 & $\begin{array}{l}\text { Utilization of Information } \\
\text { Technology }\left(\mathrm{X}_{2}\right)\end{array}$ & 0,216 & $\beta \neq 0$ & Take effect \\
\hline 3 & The Role of Internal Oversight $\left(\mathrm{X}_{3}\right)$ & 0,154 & $\beta \neq 0$ & Take effect \\
\hline 4 & Apparatus Competence $\left(\mathrm{X}_{4}\right)$ & 0,209 & $\beta \neq 0$ & Take effect \\
\hline
\end{tabular}

Based on the results of the regression tests, the multiple linear regression equation is obtained as follows:

$\mathrm{MP}=1,044+0,592 \mathrm{~PB}+0,216 \mathrm{UIT}+0,154 \mathrm{RIO}+0,209 \mathrm{AC}+\varepsilon$

\section{Discussions}

\section{Influence Participation on Managerial Budgeting Performance}

The results showed that budgetary participation had an effect on managerial performance. The regression coefficient $\left(X_{1}\right)$ obtained is 0,592 , indicating that each increase in budgeting participation of 1 unit of interval scale will be followed by an increase 


\section{International Journal of Business Management and Economic Review}

Vol. 4, No. 06; 2021

ISSN: 2581-4664

in managerial performance of 0,592 in interval scale units. Obtained a positive effect of budgetary participation on managerial performance. This means that if the apparatus participates in budgeting each SKPK in Aceh Singkil Regency, the managerial performance will get better.

Based on the results of the questionnaires collected from research respondents, it is known that the budget compilers in each SKPK always participate in SKPK budgeting. Apart from participating, the budget drafting apparatus also contributed in the form of program ideas and provided opinions regarding SKPK budget preparation.

This means that participation in budgeting allows subordinates to communicate what they need to their superiors and participation can allow subordinates to choose actions that can build commitment and are considered responsible for what has been chosen. That way, the subordinates will be serious in achieving the budget target because they are involved in the preparation. So that by doing so, the budget that has been prepared can be realized properly and in the end can improve SKPK's managerial performance.

The results of this study are in accordance with the results of research conducted by Sukandani and Istikhoroh (2016) with the results that budgetary participation has an effect on managerial performance at the Office in East Java Province. The results of this study are in line with the results of Friyanty's (2016) research which shows that budget participation has a significant effect on the managerial performance of the Indramayu local government apparatus. This means that the more active the involvement of budget users in budgeting, the higher the managerial performance.

\section{Effect of Information Technology Utilization on Managerial Performance}

The results showed that the use of information technology affect the performance of ma najerial. The regression coefficient $\left(\mathrm{X}_{2}\right)$ obtained is 0,216 , indicating that each increase in the use of information technology of 1 interval scale unit will be followed by an increase in managerial performance of 0,216 interval scale units. Obtained the positive influence of the use of information technology on managerial performance. This means that if information technology is properly utilized by officials in each SKPK in Aceh Singkil District, managerial performance will increase.

Based on the results of questionnaires collected from research respondents, it is known that every SKPK in Aceh Singkil District has provided hardware such as computers and software such as software in government activities, including in terms of financial management. The apparatus also gives an average answer that has used the available facilities and understands how to use it so that it is useful in completing the field of work of each apparatus, especially in producing information to the parties in need.

The results of this study are in line with the theory put forward by Thompson, Higgins and Howell (1991) which states that optimizing information technology can be done by improving the user's performance, but that does not mean that every individual positively accepts the existence of this technology and can feel its benefits. Ariyanto (2007) states that the use of appropriate information system technology which is then equipped with users who are experts in using it will be able to improve organizational performance and the performance of the individual concerned. 


\section{International Journal of Business Management and Economic Review}

Vol. 4, No. 06; 2021

ISSN: 2581-4664

The results of this study are in accordance with the results of research conducted by Sari, Basri and Indriani (2017) which prove that the use of information technology has an effect on the managerial performance of financial management at the Regional Government SKPK of Aceh Jaya Regency. This means that the availability of timely information with accurate, strategic, tactical data every day enables management to use the information at any time and becomes accurate input into the decision-making process. With the use of information technology, good managerial performance in financial management will be achieved. These results are also in accordance with the results of Wasito's (2012) research which proves that the use of information technology has an influence on individual/managerial performance at the Muhammadiyah University of Surakarta.

\section{The Influence of the Role of Internal Control on Managerial Performance}

The results showed that the role of internal control had an effect on managerial performance. The regression coefficient $\left(\mathrm{X}_{3}\right)$ obtained is 0,154 indicating that each increase in the role of internal control by 1 unit of interval scale will be followed by an increase in managerial performance of 0,154 interval scale units. Obtained a positive influence on the role of internal control on managerial performance. This means that if the internal supervisor plays a good role in government activities, the managerial performance will be better.

Based on the results of the questionnaires that have been collected from research respondents, it is known that officials at the SKPK in Aceh Singkil Regency on average agree that internal supervisors, namely the inspectorate have played a role in activities at SKPK, such as inspection of organizational structures, checking cash receipts and disbursements, planning activities, monitoring of workforce within the SKPK, evaluating all documents and proof of cash receipt transactions to evaluate findings related to problems in the field of financial management.

The results of this study are in line with the theory put forward by Mardi (2008) that inspectorate supervision has a very strategic role, as a catalyst and dynamist in improving apparatus performance and the success of regional development. The inspectorate functions in the process of reviewing financial reports to determine whether the financial statements have been presented in accordance with applicable regulations. The input provided by the inspectorate in this review process will guide the realization of SKPK financial reports that are in accordance with SAP and will describe the expected performance achievements. So it can be concluded that the better the inspectorate's supervision, the better the SKPD's managerial performance. In addition, according to PP. 41 of 2007, the main objective of inspectorate supervision is not only to carry out verification actions, but also to assist the supervised party in carrying out their duties properly in order to improve the performance of the organization being supervised.

The results of this study are in accordance with the results of research conducted by Puspita (2018) and Sari (2015 which proves that inspectorate supervision has a significant positive effect on SKPK managerial performance. This means that the relationship between inspectorate supervision is in line with SKPD managerial performance .

\section{Effect of Apparatus Competence on Managerial Performance}

The results showed that the competence of the apparatus had an effect on managerial performance. The regression coefficient $\left(\mathrm{X}_{4}\right)$ obtained is 0,209 , indicating that each increase in the competence of the apparatus by 1 interval scale unit will be followed by an increase in managerial 


\section{International Journal of Business Management and Economic Review}

Vol. 4, No. 06; 2021

ISSN: 2581-4664

performance of 0,209 interval scale units. Obtained a positive influence of apparatus competence on managerial performance. This means that if the apparatus at the SKPK in Aceh Singkil Regency has a good level of competence, it will improve managerial performance.

Based on the results of questionnaires that have been collected from research respondents, it is known that officials at the SKPK in Aceh Singkil Regency have expertise, understanding and knowledge in the field of financial management such as carrying out bookkeeping, administering financial reports, and other knowledge related to accounting science. On average, SKPK officials have understood and implemented Government Regulation Number 71 Year 2010 regarding government accounting standards as a reference in preparing SKPK financial reports.

The results of this study are in line with the theory put forward by Sari, Basri and Indriani (2017) which proves that the competence of the apparatus affects the managerial performance of financial management in the Regional Government SKPK of Aceh Jaya Regency. The results of this study are also in accordance with the results of research conducted by Wasana and Wirajaya (2015) which proved that competence has a positive effect on the Managerial Performance of Rural Banks in Gianyar Regency. This means that a competent manager is able to coordinate his subordinates to work together to achieve optimal BPR goals. Competence is a characteristic that underlies a person to achieve high performance in his job. Employees who do not have sufficient knowledge at work will encounter many obstacles that result in waste of materials, time and energy.

\section{CONCLUSIONS AND SUGGESTIONS Conclusions}

The participation in budgeting, the use of information technology, the role of internal control and the competence of the apparatus both have a significant influence on managerial performance of SKPK of Aceh Singkil.

\section{Recommendations}

1. Given the importance of budgeting participation set out in the budget, which in turn has implication for the achievement of the vision and mission of the local government, the whole SKPKs in the district government should pay more pay attention on the budget preparation process and the involvement of related apparatus and guided by financial management regulations.

2. In terms of the use of information technology and apparatus competence, officials working in the district government agencies should be given education and training on accounting software or software used in their field of work. This is one form of local government steps toward in increasing the capacity of human resources in the use of information technology. In turn, the maximum use of information technology by the apparatus will improve the performance of the apparatus itself.

\section{REFERENCES}

Ariyanto, D. 2007. Pengaruh Efektivitas Penggunaan dan Kepercayaan Teknologi Sistem Informasi Akuntansi terhadap Kinerja Individual. Jurnal Akuntansi dan Bisnis, 3(1), 2333.

Bangun, A. (2009). Pengaruh Partisipasi Dalam Penyusunan Anggaran, Kejelasan Sasaran Anggaran dan Struktur Desentralisasi Terhadap Kinerja Manajerial SKPD Dengan 


\section{International Journal of Business Management and Economic Review}

Vol. 4, No. 06; 2021

ISSN: 2581-4664

Pengawasan Internal Sebagai Variabel

Pemoderasi. Tesis. Sekolah Pascasarjana

Universitas Sumatera Utara Medan.

Barus, S. (2019). Apel Gabungan, Wabup Aceh Singkil Soroti E- Kinerja ASN. Artikel online diakses melalui http://rri.co.id 20/09/2019.

Brownell, P. (1982). Participation in Budgeting Process: When It Works and When It Doesn't. Journal of Accounting Literature, 1, 124-153.

Celviana, W., \& Rahmawati. (2010). Pengaruh SDM dan Pemanfaatan Teknologi Informasi Terhadap Keterandalan dan ketepatwaktuan Pelaporan Keuangan Pemerintah daerah dengan variabel intervening pengendalian intern akuntans, studi empiris, di pemda subosukawonoseraten. Simposium Nasional Akuntansi XII Purwakarta.

Chabib, S. (2011). Menilai Kinerja Pemerintah Daerah. Fokus Media. Bandung.

Coryanata, I. (2004). Pelimpahan Wewenang dan Komitmen Organisasi dalam antara Partisipasi Penyusunan Anggaran dan Kinerja Manajerial. Simposium Nasional Akuntansi (SNA) VII.

Friyanty, I. (2016). Faktor- Faktor Yang Mempengaruhi Kinerja Manajerial Aparat Pemerintahan. TEKUN, VII (01), $62-79$.

Hidayat, T. (2014). Analisis Faktor-Faktor Yang Mempengaruhi Kinerja Manajerial. Akuntabilitas, VII (1), 56-68.

Jurnali, T. \& B. Supomo. (2002). Pengaruh Faktor Kesesuaian Tugas-Teknologi dan Pemanfaatan TI terhadap Kinerja Akuntan Publik. Jurnal Riset Akuntansi Indonesia, 5 (2), 214-228.

Leach-Lopez, M. A. (2007). Differences in the Role of Job-Relevant Information in The Budget Participation- Performance Relationship among U.S. and Mexican Managers: A Question of Culture or Communication, Journal of Management Accounting Research, 19, 105-136.

Mahoney, T.A. Jardee \& S, J. Caroll. (1963). Development of Managerial Performance: $\quad$ A Research Approach. Cincinati, Ohio. Southwestern Publishing, Co.

Mardiasmo. (2002). Otonomi dan Manajemen Keuangan Daerah. Edisi Pertama. Yogyakarta. Andi

McClelland, D. C. (1973). Testing For Competence Raher Than Intellegence. American Psychologist, 28 (1), 1-14.

Mifti, S., N. B. Lestariyo, \& A. Kowanda. 2009. Pengawasan Internal dan Kinerja (suatu kajian di kantor Inspektorat Jenderal Departemen Dalam Negeri). Jurnal Ekonomi Bisnis. 3 (14), 114-124.

Milani, K. (1975). The Relationship of Participation in Budget Setting to Industrial Supervisor Performance Attitudes: A. Field Study. Accounting Review. 274-284.

Munandar. (2000). Budgeting;Perencanaan Kerja, Pengkoordinasian Kerja, dan

O'Brien, \& A. James. (2006). Pengantar Teknologi Sistem Informasi Perspektif Bisnis dan Manajerial. Jakarta: Salemba Empat.

Pengawasan Kerja. Yogyakarta: BPFE.

Puspita, C. C. A. (2018). Pengaruh Partisipasi Anggaran, Sistem Pengendalian Internal, Komitmen Organisasi Dan Kepuasan Kerja Terhadap Kinerja Manajerial. Artikel Publikasi. Universitas Bandar Lampung.

Rasuli, L. O., \& A. Lukum. (2012). Pengaruh Karakteristik Sasaran Anggaran Terhadap Kinerja Manajerial Organisasi Pada Universitas Negeri Gorontalo. Artikel online melalui repository.ung.ac.id. Diakses pada 20/09/209. 
Vol. 4, No. 06; 2021

ISSN: 2581-4664

Revika, R. (2015). Pengaruh Kualitas Sumber Daya Manusia, Komitmen Organisasi, Komunikasi Organisasi, dan Partisipasi Anggaran terhadap Kinerja Satuan Kerja Perangkat Daerah (SKPD) di Kota Payakumbuh. JOM FEKON, 2 (1), 1-15.

Sabeni, A., \& I. Gozali. (2001). Pokok-pokok Akuntansi Pemerintahan. Edisi 4. Yogyakarta. BPFE.

Sari, M., H. Basri \& M. Indriani. (2017). Pengaruh Pemanfaatan Teknologi Informasi, Kompetensi Aparatur Dan Komitmen Organisasi Terhadap Kinerja Manajerial Pengelolaan Keuangan Pada Satuan Kerja Perangkat Kabupaten Pemerintah Daerah Kabupaten Aceh Jaya. Jurnal Megister Akuntansi Pascasarjana Universitas Syiah Kuala, 6 (2), 67-73.

Sari, R. N. (2015). Pengaruh Pengawasan Inspektorat Dan Partisipasi Dalam Penyusunan Anggaran Terhadap Kinerja Manajerial SKPD. Artikel Publikasi. Universitas Negeri Padang.

Sukandani, Y., \& S. Istikhoroh. (2016). Participatory Budgeting Role in Improving the Performance of Managerial Head of Department East Java. Review of European Studies, 8 (4), 148-157.

Supomo \& Indriantoro. (1998). Pengaruh Struktur dan Kultur Organisasi terhadap Keefektifan Anggaran Partisipatif dalam Peningkatan Kinerja Manajerial. Kelola. VII (18).

Supriono, A. (2005). Pengantar Teknologi Informasi. Semarang : Salemba Infotik.

Sutarman. (2009). Pengantar Teknologi Informasi. Jakarta: Bumi Aksara.

Sutrisno, E. (2009). Manajemen Sumber Daya Manusia. Edisi pertama. Jakarta: Kencana Prenada Media Group.

Thompson, R. L. \& W. C. Baril. (2005). Information Technology and Management. Mc GrawHill.

Wasana, J. K. H., \& I G. A. Wirajaya. (2015). Pengaruh Kompetensi, Motivasi, Dan Komitmen Organisasi Pada Kinerja Manajerial Bank Perkreditan Rakyat Sekabupaten Gianyar. E-Jurnal Akuntansi Universitas Udayana, 13 (3), 828-856

Wasito, E. (2012). Pengaruh Informasi Akuntansi, Pemanfaatan Teknologi Informasi, Dan Sistem Akuntansi Manajemen Terhadap Kinerja Manajerial. Artikel Publikasi. Universitas Muhammadiyah Surakarta.

Wulandari, N. E. (2011). Pengaruh Partisipasi Penyusunan Anggaran Terhadap Kinerja Aparat Pemerintah Daerah: Kepuasan Kerja dan Komitmen Organisasi Sebagai Variabel Moderating. Artikel Publikasi, Universitas Diponegoro, Semarang. 